\title{
STUDI PEMBUATAN BISKUIT FUNGSIONAL DENGAN SUBSTITUSI TEPUNG IKAN GABUS DAN TEPUNG DAUN KELOR
}

\author{
Rina Sugiarti Dwi Gita ${ }^{2}$, Sarwo Danuji² \\ IKIP PGRI Jember ${ }^{1,2}$ \\ rina_gita16@yahoo.com ${ }^{1}$
}

\begin{abstract}
ABSTRAK
Tujuan dari penelitian ini adalah untuk mengetahui kandungan zat gizi makro dan mikro biskuit tepung daun kelor dan ikan gabus. Jenis penelitian adalah eksperimen (experimental research) yang dilakukan di laboratorium. Alat yang digunakan dalam penelitian ini adalah penghalus daging/blender, saringan, oven, talenan, pisau, baskom, panic, sarung tangan, kompor, Loyang, nyiru, mixer, piring kecil, timbangan, plastik segitiga. Hasil penelitian menunjukkan bahwa dari 6 formula yang dibuat produk yang telah memiliki nilai paling tinggi yaitu berdasarkan uji organoleptik dengan metode test hedonik adalah formula B5 yang kemudian formula tersebut dianalisis kandungan zat gizi makro dan zat gizi mikonya. Hasil analisis terhadap kandungan zat gizi makro menunjukkan kadar air pada biskuit yang dihasilkan adalah 5,04\%. Kadar abu biskuit 1,60\%. Kadar lemak 31,67\%. Kadar protein 19,24\%. Kadar karbohidrat 42,74\%. Hasil analisis terhadap kandungan zat gizi mikro menunjukkan bahwa Magnesium yang dihasilkan 12,69\%. Calsium 96,06 \%. Zn 0,04\%. Vitamin C 69,99\%. Vitamin A $259,4 \%$. Fosfor $19,92 \%$. Simpulan, poduk biskuit tepung daun kelor dan ikan gabus yang dihasilkan memiliki kandungan zat gizi dan memenuhi persyaratan standar SNI pembuatan biskuit .
\end{abstract}

Kata Kunci: daun kelor, ikan gabus, biskuit

\begin{abstract}
The objective of the study was to find out the content of macro and micro nutrient in kelor leaves biscuits flour and snakehead fish. The study was an experimental study which was conducted at the laboratory. The instruments used were blender, filter, oven, chopping block, knife, basin, panic, gloves, stove, baking pan, flat basket, mixer, small plate, weighing scale, and triangle plastic. The result of the study indicated that out of 6 formula from the product which has the highest value, such as based on organoleptic test, with hedonic test method, was formula B5. Then the macro and micro nutrient of the formula was analyzed. The result of the analysis showed the water content was 5,04\% in the biscuits. The ashes content was $1,60 \%$. The fat content was $31,67 \%$. The protein was 19,24\%. The carbohydrate was $42,74 \%$. The analysis result on the micro nutrient showed the. Magnesium was 12,69\%, Calsium 96,06 \%, Zn 0,04\%, Vitamin C 69,99\%, Vitamin A 259,4\%, Fosfor 19,92\%. In conclusion, kelor leaves biscuits flour and snakehead fish, which was produced, contain some nutrients which meet the SNI requirements of biscuits production.
\end{abstract}

Keywords: kelor leaves, snakehead fish, biscuits 


\section{PENDAHULUAN}

Salah satu faktor dalam menentukan adanya kualitas sumber daya manusia (SDM) adalah status gizi. Sedangkan status gizi adalah keadaan didalam tubuh sebagai reaksi dari konsumsi penggunaan zat-zat gizi dan makanan (Azizah, 2015). Salah satu upaya dengan mengkonsumsi ikan gabus yang kaya akan adanya kandungan gizi yaitu dapat memperbaiki pola konsumsi pangan agar dapat menanggulangi dan mengantisipasi kekurangan gizi yang terjadi diseluruh kalangan masyarakat luas (Rudianto, 2013).

Ikan gabus adalah ikan air tawar yang banyak ditemukan di Indonesia, secara uji klinis ikan gabus memiliki banyak manfaat yang baik khususnya bagi kesehatan tubuh manusia karena mengandung banyak kadar protein yang tinggi hinggamencapai $25,2 \%$ b/b (Setiawan, 2013). Protein yang terdapat pada ikan gabus ini sangat penting bagi tubuh manusia karena dapat membantu adanya pertumbuhan, alat pengangkut dan sistem pergerakan (Winarno, 2008). Disamping itu ikan gabus memiliki kandungan albumin yang cukup tinggi, yang berguna untuk membantu proses penyembuhan luka pasca operasi (Setiawan, 2013).

Menurut Krisnadi (2015), kandungan nutrisi daun kelor (dalam keadaan kering dijadikan tepung) dapat bermanfaat untuk perbaikan gizi yang mengandung protein setara 9 kali protein dalam yoghurt, 15 kali kalium dalam pisang serta dari segi ekonomi, 25 kali zat besi dalam bayam, 17 kali kalsium dalam susu, 10 kali vitamin A dalam wortel, $1 / 2$ kali vitamin $C$ dalam jeruk, selain daun kelor mudah didapat juga termasuk bahan yang murah.

Biskuit merupakan produk olahan makanan kering yang dibuat dengan cara memanggang adonan yang diantaranya mengandung bahan dasar lemak, terigu dan bahan pengembang dengan atau tanpa adanya penambahan bahan makanan tambahan lain yang porsi takaran kadar protein tidak boleh kurang dari 9\% serta kadar air tidak boleh melebihi dari 5\% (Wiajaya, 2010).

Pemanfaatan tepung ikan gabus dan daun kelor dalam campuran pembuatan biskuit, dimana kandungan utama ikan gabus adalah albumin yang berfungsi meningkatkan kadar albumin didalam darah juga membantu penyembuhan beberapa penyakit (Pangaribuan, 2013). Sedangkan penambahan daun kelor yaitu memiliki kandungan nutrisi berbagai jenis vitamin dan mineral serta untuk meningkatkan nilai ekonomis daun kelor yang banyak terdapat di daerah Indonesia (Zakaria, 2012).

Berdasarkan uraian tersebut di atas, maka dapat dikatakan bahwa ikan gabus dan daun kelor memiliki kandungan gizi yang tinggi. Atas dasar masalah tersebut kami memiliki inisiatif untuk melakukan pengkajian tentang penggunaan ikan gabus dan daun kelor untuk dijadikan bahan tambahan dalam pembuatan biskuit yang memiliki nilai gizi tinggi. 


\section{METODE PENELITIAN}

Jenis penelitian adalah eksperimen (experimental research) yang dilakukan di laboratorium dengan studi pembuatan biskuit dari tepung ikan gabus dan daun kelor. Alat yang digunakan dalam penelitian ini adalah penghalus daging/blender, saringan, oven, talenan, pisau, baskom, panic, sarung tangan, kompor, Loyang, nyiru, mixer, piring kecil, timbangan, plastik segitiga.

Populasi dalam penelitian ini adalah biskuit daun kelor dan ikan gabus yang telah dibuat. Sedangkan sampel adalah olahan produk biskuit sebagi produk eksperimen dan kandungan gizi makro dan mikro pada biskuit yang yang telah dibuat, sampel pada penelitian ini yaitu dilakukan uji organoleptic dengan menggunakan metode tes hedonic yang telah dibuat. Analisis data pada penelitian ini yaitu analisis laboratorium terhadap kandungan zat gizi makri dan mikro pada produk biskuit. Data yang disajikan berupa gambar, tabel dan grafik.

Penelitian dilakukan di laboratorium FMIPA IKIP PGRI Jember untuk pembuatan biskuit ikan gabus dan daun kelor dengan uji organoleptik. Penelitian dilakukan mulai bulan Mei sampai dengan Agustus 2018. Percobaan untuk mendapatkan biskuit yang bergizi tinggi ini menggunakan metode eksperimen dan analisa laboratorium. Terdapat 6 formula produk biskuit daun kelor dan ikan gabus yang dibuat dengan rincian:

B1: Tepung Terigu $0 \%+$ Tepung Ikan gabus $50 \%+$ Tepung daun kelor $50 \%$ B2: Tepung Terigu $20 \%$ + Tepung Ikan gabus $40 \%$ + Tepung daun kelor $40 \%$ B3: Tepung Terigu $40 \%+$ Tepung Ikan gabus $30 \%+$ Tepung daun kelor $30 \%$ B4: Tepung Terigu $60 \%+$ Tepung Ikan gabus $20 \%+$ Tepung daun kelor $20 \%$ B5: Tepung Terigu $80 \%$ + Tepung Ikan gabus $10 \%$ + Tepung daun kelor $10 \%$ B6: Tepung Terigu $100 \%+$ Tepung Ikan gabus $0 \%+$ Tepung daun kelor $0 \%$

\section{HASIL PENELITIAN}

Uji organoleptik dengan metode test hedonik dilakukan untuk mengetahui pada tingkat kesukaan oleh konsumen tehadap 30 panelis. Analisa data penelitian ini yaitu analisis laboratorium berupa kandungan zat gizi makro (kadar lemak, kadar protein, kadar abu, serta kadar karbohidrat) dan mikro (Albumin, Mg, Ca, Zn, Vitamin C, dan Fosfor). Hasil penelitian biskuit tepung daun kelor dan ikan gabus berupa pengujian organoleptic dapat disajikan dalam bentuk Tabel 1 berikut:

Tabel I. Hasil Uji Organoleptik

\begin{tabular}{cccc}
\hline No. & Hasil & Rincian Bahan produk & \multicolumn{1}{c}{ Minat } \\
Produk Biskuit & & Biskuit & 30 Responden \\
\hline 1 & & $\begin{array}{l}\text { Tepung Terigu 0 \% + Tepung } \\
\text { Ikan gabus 50\% + Tepung } \\
\text { daun kelor 50\% }\end{array}$ & $\begin{array}{l}\text { Semua responden tidak } \\
\text { menyukai biskuit }\end{array}$ \\
& & & \\
& & & \\
\hline
\end{tabular}




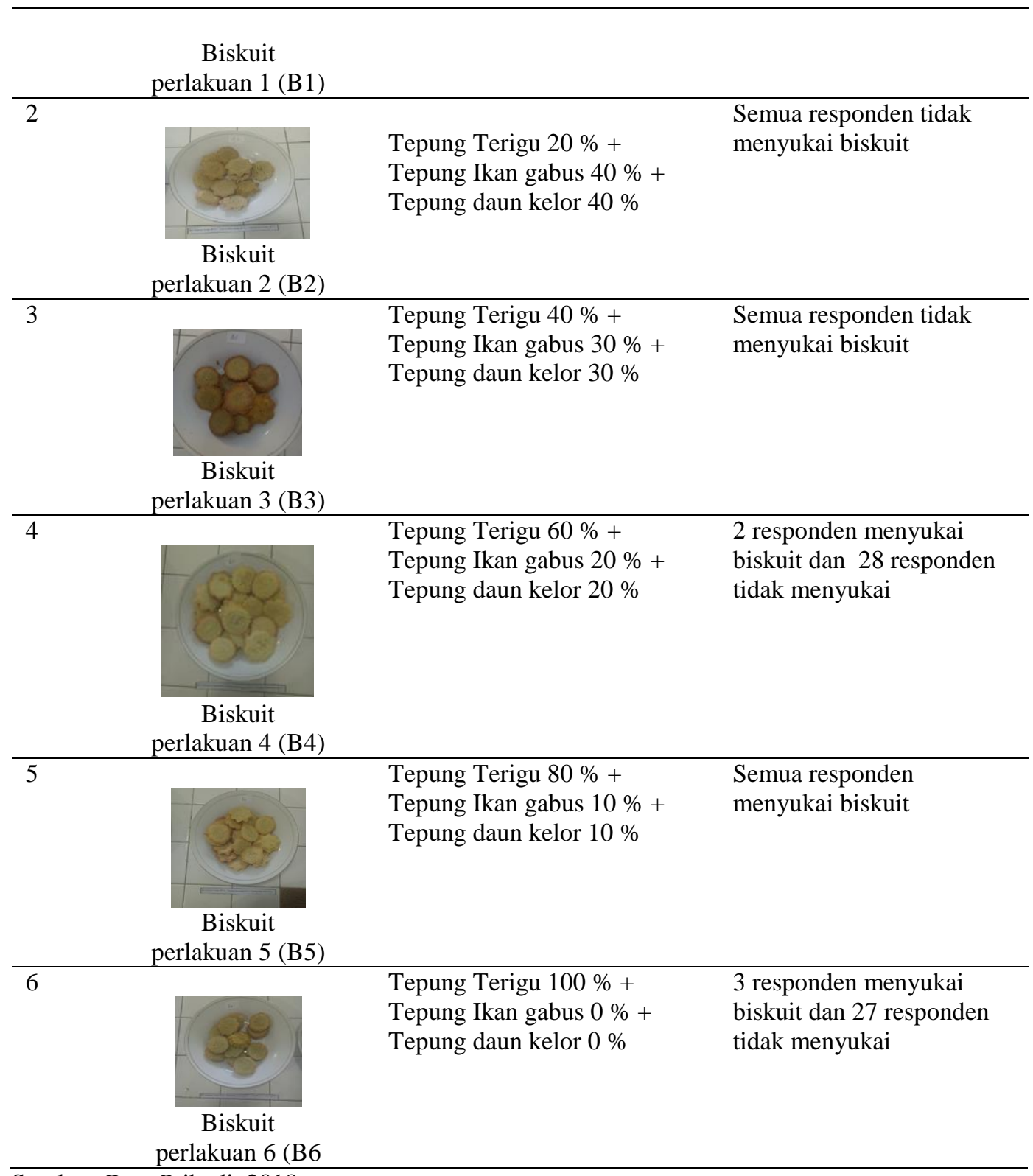

Sumber: Data Pribadi, 2018

Gambaran data hasil penelitian dapat disajikan secara sederhana yaitu dalam bentuk grafik dibawah ini:

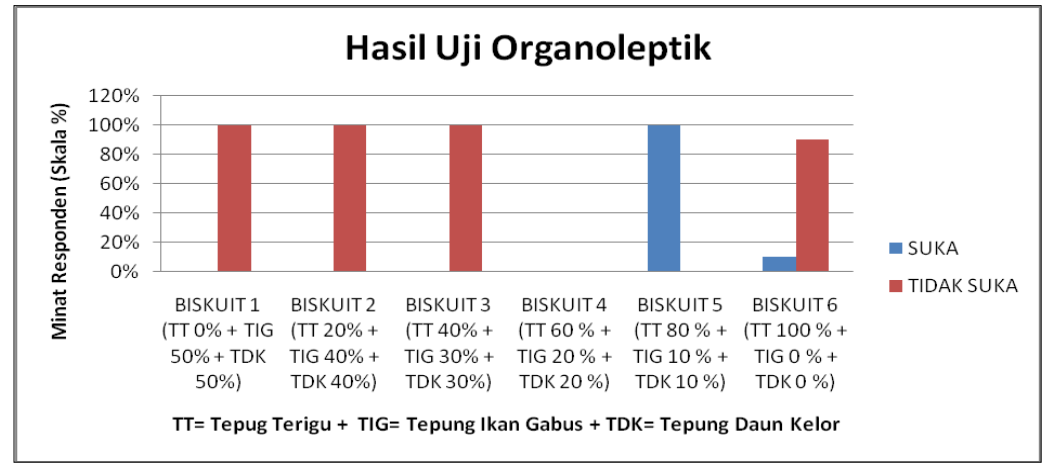

Gambar I. Hasil Uji Organoleptik 
Dari data hasil uji organoleptik menunjukkan bahwa dari 30 responden, semua responden tidak menyukai biskuit B1 karena memiliki rasa manis dan pahit dikarena tidak mengandung tepung. Hasil uji B2 menunjukkan bahwa semua responden tidak menyukai karena memiliki aroma amis yang berlebihan dari ikan gabus dan daun kelor. B3 menunjukkan bahwa dari 30 responden, semua responden tidak menyukai biskuit karena rasa biskuit rasanya terasa aneh. B4 menunjukkan bahwa terdapat 2 responden menyukai biskuit karena rasa manisnya tidak berlebih dan aroma ikan gabus dan daun kelor sedikit berkurang, dan sisanya 28 responden tidak menyukai karena tidak menyukai aroma yang dihasilkan dari ikan gabus dan daun kelornya. B5 menunjukkan bahwa dari 30 responden, semua responden menyukai biskuit 5, karena perpaduan rasa manis dan aroma ikan gabus dan daun kelor sangat pas. Sedangkan B6 menunjukkan bahwa terdapat 3 responden dari 30 responden yang menyukai biskuit 6 , karena biskuit 6 tidak memiliki aroma ikan gabus dan daun kelor, dan sisanya 27 responden tidak menyukai karena biskuit 6 tidak memiliki rasa manis sedikitpun.

Tabel 2. Hasil Uji Laboratorium Biskuit 5: Tepung Terigu $80 \%$ + Tepung Ikan gabus $10 \%$ + Tepung daun kelor $10 \%$

\begin{tabular}{lllll}
\hline \multirow{2}{*}{ NO } & \multicolumn{5}{c}{ Kandungan Zat Gizi } \\
\cline { 2 - 5 } & \multicolumn{1}{c}{ Makro } & Rata-Rata & Mikro & Rata-Rata \\
\hline 1 & Kadar Protein & 19,24 & $\mathrm{Mg}$ & 12,69 \\
\hline 2 & Kadar Lemak & 31,67 & $\mathrm{Ca}$ & 96,06 \\
\hline 3 & Kadar Abu & 1,60 & Zn & 0,04 \\
\hline 4 & Kadar Karbohidrat & 42,74 & Vitamin A & 259,4 \\
\hline 5 & Kadar air & 5.52 & Vitamin C & 69,99 \\
\hline 6 & & & Fosfor & 19,92 \\
\hline
\end{tabular}

Sumber: Politeknik Jember, 2017

Pemilihan formulasi produk biskuit daun kelor dan ikan gabus terbaik yaitu pada perlakuan B5 yakni tepung terigu $80 \%+$ tepung ikan gabus $10 \%+$ tepung daun kelor $10 \%$. Dari data tersebut menunjukkan bahwa kadar protein sebesar 19, 24\%, kadar lemak sebesar 31,67\%, kadar abu sebesar 1,60\%, kadar karbohidrat sebesar 42,74\%, kadar air 5.52\%. Mg sebesar 12, 96 mg/100 gr, Ca sebesar 96,06 mg/100 gr, Zn sebesar 0, $04 \mathrm{mg} / 100 \mathrm{gr}$, vitamin A sebesar 259,4 $\mu \mathrm{g} / 100 \mathrm{gr}$, Vitamin C sebesar 69,99 mg/100 gr, dan fosfor sebesar 19,92 mg/100 gr yang terkandung dalam biskuit ikan gabus dan daun kelor.

\section{PEMBAHASAN}

Analisa data penelitian ini yaitu laboratorium pada kandungan zat gizi makro yang terdiri dari kadar protein yang berfungsi membentuk jaringan baru dalam masa pertumbuhan dan perkembangan tubuh, memperbaiki, memelihara dan mengganti jaringan yang rusak. Pada penelitian terdahulu yaitu oleh Fatmawati (2014) yaitu tepung ikan gabus sebagai sumber Protein (food supplement) menunjukkan hasil uji organoleptik terhadap warna, kenampakan dan tekstur tepung ikan gabus, menunjukkan bahwa tepung ikan gabus yang dibuat 
dengan cara pengukusan dan ekstraksi lemak, merupakan tepung ikan gabus yang terbaik dari hasil penelitian. Pada penelitian ini juga dilakukan sama dengan cara pengukusan dan juga terdapat penambaha bahan yaitu dengan tepung daun kelor yang memiliki nilai gizi tinggi.

Kadar protein dihasilkan 19,24\%, syarat mutu biskuit SNI 01-2973-1992 menyatakan bahwa adanya kadar protein yang terdapat pada biskuit yaitu minimal $6 \%$. Kadar protein yang telah dihasilkan berada di bawah persyaratan SNI. Kadar lemak berfungsi menyerap vitamin yang larut ke dalam lemak (ADEK), melancarkan metabolism dan membuat hormon. Syarat mutu biskuit berdasrakan SNI 01-2973-1992 adalah 9,5 \%. Kadar lemak pada penelitian ini adalah 31,67\%. Kadar lemak memenuhi persyaratan mutu biskuit SNI.

Kadar abu yang dihasilkan pada penelitian ini adalah 1,60\%. Syarat mutu biskuit berdasrakan SNI 01-2973-1992 adalah 1,6\%. Kadar abu memenuhi persyaratan mutu biskuit SNI. kandungan abu yang terdapat pada suatu bahan pangan menunjukkan bahwa residu bahan anorganik yang tersisa adalah setelah bahan orgnik pada makan didekstruksi. Kadar abu dari suatu bahan biasanya menunjukkan kadar mineral, kemurnian, serta kebersihan suatu bahan yang dihasilkan. Hal ini sesuai dengan pendapat Almatsier (2010), bahwa kandungan mineral pada sayuran berbeda-beda dan buah-buahan, hal ini tergantung pada beberapa faktor antara lain : genetik, agriculturalpractices, variasi kandungan mineral di dalam tanah, penggemukan $\mathrm{pH}$ dan tanah, serta kematangan lahandan faktor lingkungan. Kandungan abu dapat digunakan untuk memperkirakan kandungan dan keaslian bahan yangdigunakan;

Bahan yang terdapat pada sumber makanan biskuit adalah karbohidrat antara lain tepung terigu, susu dan gula. Hasil analisis menunjukkan bahwa kadar karbohidrat dengan menggunakan tepung daun kelor dan ikan gabus pada penelitin ini adalah 42,74\%. Nilai tersebut memenuhi standar SNI yaitu $70 \%$. Kadar karbohidrat memberikan energi yang cukup besar bagi tubuh untuk bekerja dengan baik. Hal ini sesuai dengan pendapat Graha (2010), yaitu dalam mengkonsumsi karbohidrat harus seimbang antara pemasukan dan pengeluaran maka energy yang tidak digunakan disimpan di dalam tubuh yaitu dalam bentuk lemak

Kadar kalsium (Ca) yang dihasilkan pada bisuit penelitian ini adalah 96,06 mg/100 gr. Nilai tersebut sesuai dengan informasi rinci komposisi kandunga nutrisi gizi pada biskuit yaitu $62 \mathrm{mg}$. Kalsium (Ca) berfungsi membantu pembentukan tulang dan gigi dan mengatur proses biologis dalam tubuh sesuai pendapat Padmasuri (2015), menyatakan keperluan kalsium terbesar pada waktu pertumbuhan, juga keperluan-keperluan kalsium masih diteruskan meskipun sudah mencapai usia dewasa, pada pembentukan tulang, bila tulang baru dibentuk maka tulang yang sudah tua dihancurkan yaitu secara simultan.

Kadar air yang dihasilkan pada biskuit tepung kelor dan ikan gabus adalah $5.52 \%$ yaitu memenuhi standar SNI yaitu sebsar 5\%. Kadar air berfungsi 
menentukan kesegaran dan daya awet pada bahn pangan hal tersebut sesuai dengan pendapat Winarno (2008), mengakatan bahwa bentuk kadar air yang sangat tinggi akan mengakibatkan mudahnya masuk bakteri, khamir dan kapang untuk berkembang biak sehingga terjadi perubahan pada bahan pangan yang dapat mempercepat adanya pembusukan.

Selain kandungan gizi makro terdapat pula kandungan gizi mikro yaitu seperti Magnesium (Mg) merupakan salah satu nutrien paling penting untuk kesehatan jantung sesuai pendapat Andarini (2012), Menyatakan apabila kebutuhan magnesium tidak terpenuhi, akan terjadi penurunantekanan darah karena fungsi magnesium sebagai perelaksasi otot polos vascular sehingga akan terjadi detakan jantung yang tidak normal; Zn banyak dibutuhkan oleh berbagai macam organ tubuh, seperti mukosa saluran cerna, kulit, dan hampir semua sel yang membutuhkan mineral ini sesuai pendapat Widhayari (2012), mengatakan Dampak yang ditimbulkan akibat adanya kurangnya mineral ini yaitu terjadinya penurunan nafsu makan pada gangguan sistem pertahanan dalam tubuh.

Vitamin $\mathrm{C}$ berfungsi sebagai antioksidan dalam tubuh sesuai pendapat Yulistiana (2016), menyatakan manfaat vitamin C antara lain antiinflamasi, antioksidan dan dapat berfungsi meningkatkan sistem imun, mekanisme antioksidan vitamin $\mathrm{C}$ mampu sebagai free radical scavenging dengan menyumbangkan elektronnya terhadap molekul radikal bebas sehingga menjadi stabil, sedangkan pada vitamin $\mathrm{C}$ menjadi bentuk radikal relatif stabil dan tidak reaktif; Vitamin A memiliki manfaat untuk pertumbuhan, penglihatan, dan meningkatkan daya tahan tubuh sesuai pendapat Tjekyan (2015), mengatakan vitamin A tidak dapat dibuat oleh tubuh, sehingga harus dipenuhi dari luar (essensial), berfungsi untuk pertumbuhan, penglihatan, dan meningkatkan daya tahan tubuh terhadap adanya penyakit.

Fosfor sebagai fosfat memiliki fungsi peranan penting yaitu dalam fungsi sel hidup dan struktur sesuai pendapat Sulistyoningsih (2017), mengatakan Fosfor berfungsi sebagai pembentuk tulang, persenyawaan organik, karbohidrat metabolisme energi, lemak dan asam amino, bagian koenzim dan transportasi asam lemak.

\section{SIMPULAN}

Hasil analisis terhadap kandungan zat gizi mikro menunjukkan bahwa Magnesium yang dihasilkan 12,69\%. Calsium 96,06 \%. Zn 0,04\%. Vitamin C 69,99\%. Vitamin A 259,4\%. Fosfor 19,92\%. Produk biskuit tepung daun kelor dan ikan gabus yang dihasilkan memiliki kandungan zat gizi dan memenuhi persyaratan standar SNI pembuatan biskuit . 


\section{DAFTAR PUSTAKA}

Adriani, M., \& Wirjatmadi, B. (2012). Pengantar Gizi Masyarakat. Jakarta: Kencana Prenada Media Group

Almatsier, S. (2010). Prinsip Dasar Ilmu Gizi. Jakarta: PT Gramedia Pustaka Utama

Azizah, A. A. (2015). Tingkat Kerapuhan dan Daya Terima Biskuit Yang Disubsitusi Tepung Daun Kelor (Moringa oleifera). Naskah Publikasi. Program Studi Ilmu Gizi Fakultas Ilmu Kesehatan Universitas Muhammadiyah.

Fatmawati. (2014). Tepung ikan gabus sebagai sumber Protein (FOOD SUPPLEMENT). Jurnal Bionature, 15 (1); 54-60

Graha, K.C. (2010). Kolesterol. PT Elex Media Komputindo. Jakarta.

Krisnadi, A. Dudi. (2015). Kelor Super Nutrisi.kelorina.com. Pusat Informasi dan Pengembangan Tanaman Kelor Indonesia. Lembaga Swadaya MasyarakatMedia Peduli Lingkungan (LSM-Mepeling). http://kelorina.com/ebook.pdf. Diakses pada tanggal 06 Agustus 2016.

Padmasuri. K, (2015). Im A Happy Vegetarian, Gaya Hidup Sehat dengan ResepResep Vegetarian Pilihan, Yogyakarta: OCTOPUS Publishing House

Sulistyoningsih, M., Renni, R., \& Wonaerika. A. (2017). Kandungan Fosfor Dan Kalsium Daging Akibat Pemberian Tambahan Kunyit Jahe Dan Salam Pada Ransum Bebek. Jurnal Pangan Dan Gizi, 7(2): 124-131

Pangaribuan. (2013). Substitusi Tepung Talas Belitung pada Pembuatan Biskuit Daun Kelor. Program Studi Biologi Fakultas Teknobiologi Universitas Atmajaya Yogyakarta. Yogykarta.

Rudianto, H., J. H \& Irma, A. S. (2013). Biskuit Moringa Ria Sebagai Suatu Stragedi Penanggulangan Gizi Kurang dan Gizi Buruk Pada Balita Miskin Berbasis Masyarakat. Bimgi 2 (1).

SNI. (1992). Mutu dan Cara Uji Biskuit. Indonesia: SNI 01-2973-1992.

Setiawan, S., \& Daniel. T. (2013). Pemanfaatan residu daging ikan gabus (ophiocephalus striatus) dalam pembuatan kerupuk ikan beralbumin. Thpi Student Journal, 1(1); 21-32

Tjekyan. R.M \& Suryadi. (2015). Pengaruh Suplementasi Vitamin A Terhadap Lama Diare pada Anak Usia 14-51 Bulan yang Berobat di Puskesmas Sukarami Palembang. Jurnal kedokteran dan kesehatan. 2(2); 117-123

Widhyari \& Sus, D. (2012). Peran dan dampak defisiensi zinc (zn) Terhadap sistem tanggap kebal. Jurnal Wartazoa. 22(3)

Wijaya, H. (2010). Kajian Teknis Standar Nasional Indonesia Biskuit SNI 012973-1992. Balai Besar Industri Argo, Kementrian Perindustrian.

Winarno, F. G. (2008). Kimia Pangandan Gizi. Jakarta : Gramedia. Pengolahan Universitas Gadjah Mada. Yogyakarta.

Yulistiana, F. (2016). Pengaruh Vitamin C Terhadap Kadar Interleukin-6 Plasma, MDA Plasma, dan Lama Rawat Inap Penderita PPOK Eksaserbasi. Jurnal Respir Indo, 36 (3).

Zakaria. Tamrin, A., Sirajjudin \& Hartono, R. (2012). Penambahan Tepung Daun Kelor pada Menu Makan Sehari-Hari dalam Upaya Penanggulangan Gizi Kurang pada Anak Balita. Media Gizi Pangan. Edisi 1. 13(1). 